\title{
Mechanisms and Kinetics of Succinate and Propionate Degradation in Anoxic Freshwater Sediments and Sewage Sludge
}

\author{
By BERNHARD SCHINK \\ Fakultät für Biologie, Universität Konstanz, Postfach 55 60, D-7750 Konstanz, FRG
}

(Received 12 June 1984 ; revised 9 October 1984)

\begin{abstract}
The interrelation of propionate and succinate metabolism in anoxic sewage sludge and in two different anoxic lake sediments was studied. The mechanism of propionate degradation and the kinetics of propionate and succinate metabolism were analysed using specifically labelled ${ }^{14} \mathrm{C}$ tracers and gas chromatography-gas proportional counting techniques. The labels of [1$\left.{ }^{14} \mathrm{C}\right]$ propionate and $\left[1,4-{ }^{14} \mathrm{C}\right]$ succinate were transformed almost exclusively to carbon dioxide whereas the label of $\left[3^{-14} \mathrm{C}\right]$ propionate was transformed to equal amounts of methane and carbon dioxide, indicating a randomizing pathway of propionate degradation. The pool sizes of propionate and succinate $\left(0 \cdot 3-2 \cdot 3 \mu \mathrm{mol} \mathrm{I}^{-1}\right)$ were similar to each other in, but were both different between, each of the three environments studied. The turnover times of succinate were shorter than those of propionate, and the C-1 label of propionate and the C-1 and C-4 labels of succinate were metabolized far faster than the respective C-3 and C-2 and C-3 labels. These results indicate that propionate, although formed via succinate, is also degraded via succinate in the anoxic environments studied, and that succinate metabolism is at least as important as propionate metabolism in anaerobic degradation processes.
\end{abstract}

\section{INTRODUCTION}

Propionate and succinate are important products of anaerobic fermentations. Propionate is formed from sugars and lactate by the classical Gram-positive propionibacteria as well as by several Gram-negative anaerobes including Selenomonas, Veillonella, Pectinatus (Lee et al., 1978) and Propionispira sp. (Schink et al., 1982). Several amino acids can be fermented to propionate, too (Elsden \& Hilton, 1978), as can ethanol and 2,3-butanediol (Samain et al., 1982; Laanbroek et al., 1982; Schink, 1984). Succinate is formed from sugars by Pectinatus sp. (Lee et al., 1978) and by typical gastrointestinal bacteria: Bacteroides succinogenes (Scheifinger \& Wolin, 1973), Ruminococcus sp., Succinivibrio sp. (Bryant \& Small, 1956) and Succinimonas sp. (Bryant et al., 1958). The reduction of aspartate, fumarate, or malate, e.g. by Wolinella succinogenes (formerly Vibrio succinogenes), also leads to succinate as an end product (Iannotti et al., 1973).

The degradation of propionate and succinate has been studied in several metabolic groups of anaerobic bacteria. In the presence of sulphate, sulphate-reducing bacteria of the genus Desulfonema can oxidize succinate completely to carbon dioxide (Widdel et al., 1983). In the rumen of cattle and sheep, succinate is converted to propionate by, for example, Selenomonas ruminantium (Scheifinger \& Wolin, 1973) and the propionate thus formed is used by the animal host (Wolin, 1979). Conversion to propionate by Selenomonas ruminantium, Veillonella alcalescens or Propionibacterium sp. (Yousten \& Delwiche, 1961) was also assumed to be the main path of succinate degradation in other anoxic habitats, and this reaction was considered to be a simple decarboxylation reaction that was not linked to energy metabolism. Recent studies have revealed that degradation of succinate to propionate proceeds via the methylmalonyl-CoA pathway and can also contribute to the energy budget of the bacterium (Hilpert \& Dimroth, 1982; Hilpert et al., 1984). 
Degradation of propionate takes different routes in the presence or absence of sulphate. In sulphate-rich environments, propionate is oxidized to acetate and carbon dioxide by, for example, Desulfobulbus propionicus (Widdel \& Pfennig, 1982). In sulphate-poor environments such as freshwater lake sediments or sewage digestors, fermentative degradation of propionate to acetate and carbon dioxide with concomitant syntrophic methanogenic reduction of carbon dioxide is accomplished by organisms like Syntrophobacter wolinii (Boone \& Bryant, 1980). Since propionate degradation in methanogenic enrichments is thought to proceed via succinate (Koch et al., 1983), the question arises as to how succinate and propionate metabolism are linked and what their relative importance is in the natural habitat.

The aim of the present study was to examine whether propionate degradation really proceeds via succinate in the natural environment, and to examine by kinetic studies the possible linkage of succinate and propionate metabolism, as well as their importance compared to acetate metabolism in anoxic habitats.

\section{METHODS}

Environments and sampling procedures. Sediment samples from two lakes and anoxic sewage sludge from a municipal sewage treatment plant were collected during June and July 1983. Lake Mendota is a moderately eutrophic dimictic hard-water lake of glacial origin in southern Wisconsin, USA. It covers about 3900 ha and has a maximum depth of $23 \mathrm{~m}$ at the site where the samples were taken. During summer stratification, which starts usually in early June, the lake becomes anaerobic up to $10.5 \mathrm{~m}$ depth. The sediment $\mathrm{pH}$ is $7 \cdot 0$, and the temperature varied during the sampling period between 8 and $10^{\circ} \mathrm{C}$. Knaack Lake is a small $(1 \cdot 1 \mathrm{ha})$ dystrophic, meromictic lake in central Wisconsin, USA, and has a maximum depth of $22 \mathrm{~m}$. During summer stratification, only the upper $3 \mathrm{~m}$ of the water column are oxygenated, and the autumn turnover mixes only the upper 12 to $14 \mathrm{~m}$. The monimolimnion and the sediment stay anoxic throughout the year at a temperature of $4{ }^{\circ} \mathrm{C}$ and at $\mathrm{pH} 6 \cdot 1-6 \cdot 2$.

Samples were taken at intervals of 3-4 weeks using an Eckman dredge. The upper 2-3 cm of the sediment were collected and transferred into glass bottles, which were then sealed under nitrogen gas with rubber stoppers. Samples were cooled in an ice box and taken to the laboratory immediately.

Sewage sludge was taken from the anoxic digestor of the Nine Springs municipal waste treatment plant in Madison, Wisconsin, USA. The in situ temperature was $32^{\circ} \mathrm{C}$, the $\mathrm{pH} 6.9$. Samples, at ambient temperature, were taken to the laboratory within $30 \mathrm{~min}$.

Pool size determinations. Large volumes of pore water (Lake Mendota, 1.8 1; Knaack Lake, 3.8 1; sewage sludge, 11) were obtained by centrifugation of the samples in a cooled centrifuge, and subsequent filtration through Whatman paper. The pore water was titrated to $\mathrm{pH} 11.0$ with small amounts of $10 \mathrm{M}-\mathrm{NaOH}$, and concentrated to small volumes $(5-20 \mathrm{ml})$ in a 'Rotavap' rotary evaporator. The concentrates were stored at $-20^{\circ} \mathrm{C}$, and were acidified with $3.3 \mathrm{M}-\mathrm{H}_{3} \mathrm{PO}_{4}$ before gas chromatographic analysis. Acetate and propionate were assayed by direct gas chromatography on Chromosorb WAW, $8 \% \mathrm{SP} 1000+1 \% \mathrm{H}_{3} \mathrm{PO}_{4}, 100-200$ mesh (Bodenseewerke PerkinElmer), column $2.0 \mathrm{~m} \times 6 \mathrm{~mm}$, at $120^{\circ} \mathrm{C}$ in a Sigma 3B gas chromatograph (Bodenseewerke Perkin-Elmer, Überlingen, FRG), equipped with a flame ionization detector and an integrator for peak area analysis. Succinate was methylated, as described by Metcalfe et al. (1966), before gas chromatography; $0.5 \mathrm{ml}$ of acidified sample was mixed with $0.5 \mathrm{ml} \mathrm{BF}_{3} /$ methanol reagent (B-1252; Sigma) and incubated overnight at $37^{\circ} \mathrm{C}$. Succinate standards were treated similarly. The methyl esters were extracted with $0.5 \mathrm{ml}$ chloroform, and the chloroform fraction was analysed by gas chromatography on 5\% FFAP-treated Chromosorb WHP, 80-100 mesh (no. 8433; Alltech, Deerfield, Ill., USA), at $130^{\circ} \mathrm{C}$ in a Packard Model 407 gas chromatograph with a flame ionization detector.

Determination of turnover times and rates. Fresh sediment and sewage sludge samples (10 $\mathrm{ml}$ of each) were transferred by syringe into anaerobic pressure tubes $\left(27 \mathrm{ml}\right.$; Bellco, Vineland, NJ, USA), gassed with $\mathrm{N}_{2} / \mathrm{CO}_{2}$ mixture $(95: 5, \mathrm{v} / \mathrm{v})$, and sealed with butyl rubber stoppers and aluminium crimps. Carrier-free radioactive tracers (about $0.5 \mu \mathrm{Ci}$ per tube; $\mathrm{I} \mu \mathrm{Ci}=37 \mathrm{kBq}$ ) were added by microlitre syringe, and the tubes were incubated at the in situ temperatures $\left(10,4\right.$ and $32^{\circ} \mathrm{C} \pm 2{ }^{\circ} \mathrm{C}$, respectively). Two or three independent turnover experiments were done with every sample, and two replicas were used with every tracer in each case. Control experiments with formaldehyde-poisoned sediment samples were done with every tracer, and did not show measurable degradation activity. Production of ${ }^{14} \mathrm{CO}_{2}$ and ${ }^{14} \mathrm{CH}_{4}$ was measured in the gas phase of the tubes by the combined gas chromatography-gas proportional counting procedures described by Nelson \& Zeikus (1974). At the end of each experiment, sediment samples were acidified, the amounts of labelled $\mathrm{CO}_{2}$ and $\mathrm{CH}_{4}$ in the headspaces were determined and the values before acidification were corrected by the Bunsen absorption coefficients for tracers dissolved or bound in the sediment phase. The recovery of radioactivity of the added tracers was $70-86 \%$.

Turnover times were calculated from plots of produced ${ }^{14} \mathrm{CH}_{4}$ and ${ }^{14} \mathrm{CO}_{2}$ versus time by extrapolating the linear part of the curves to the amount of total label turned over at the end of the experiment. The pool sizes were divided by the respective turnover times in order to obtain the turnover rates. 
Chemicals and radioactive tracers. All chemicals were of reagent or analytical grade quality. Gases were obtained from Matheson (Joliet, Ill., USA). $\left[1{ }^{14} \mathrm{C}\right]$ Acetate $\left(54.9 \mathrm{mCi} \mathrm{mmol}{ }^{-1} ; 2.03 \mathrm{GBq} \mathrm{mmol}{ }^{-1}\right),\left[2-{ }^{14} \mathrm{C}\right]$ acetate $\left(51.0 \mathrm{mCi} \mathrm{mmol}^{-1} ; 1.89 \mathrm{GBq} \mathrm{mmol}^{-1}\right),\left[3{ }^{-14} \mathrm{C}\right]$ propionate $\left(32.0 \mathrm{mCi} \mathrm{mmol}^{-1} ; 1.18 \mathrm{GBq} \mathrm{mmol}^{-1}\right)$ and $[1,4-$ ${ }^{14} \mathrm{C}$ ]succinate $\left(53.1 \mathrm{mCi} \mathrm{mmol}^{-1} ; 1.96 \mathrm{GBq} \mathrm{mmol}^{-1}\right.$ ) were obtained from New England Nuclear. Ethanol present in these tracer preparations was removed by vacuum drying after alkalinization. $[1-14 \mathrm{C}]$ Propionate $\left(57.5 \mathrm{mCi} \mathrm{mmol}^{-1} ; 2 \cdot 13 \mathrm{GBq} \mathrm{mmol}^{-1}\right)$ and $[2,3-14 \mathrm{C}]$ succinate $\left(100 \mathrm{mCi} \mathrm{mmol}^{-1} ; 3.70 \mathrm{GBq} \mathrm{mmol}{ }^{-1}\right)$ were obtained from Amersham.

\section{RESULTS}

\section{Pool size determinations}

The pool sizes of acetate, propionate and succinate were determined on separate samples taken in June and July 1983 in the sediments of Lake Mendota and Knaack Lake as well as in anoxic sewage sludge of a municipal waste treatment plant. The results are summarized in Table 1. Propionate and succinate could only be detected in concentrated pore water preparations whereas acetate could also be detected in fresh pore water preparations. Acetate concentrations measured directly and in concentrates agreed to well within $\pm 20 \%$ of error; therefore, the values obtained for propionate and succinate should not have been significantly changed by the concentration procedure. The pool sizes of acetate determined in Lake Mendota and Knaack Lake agree well with recent measurements on the same sediments (Phelps \& Zeikus, 1984; T. J. Phelps \& J. G. Zeikus, unpublished data). The pool size of acetate in the sewage sludge studied is at the lower range limit of those reported for other sewage digestor sludges (Smith \& Mah, 1966; Kaspar \& Wuhrmann, 1978). In the two sediments and the sludge studied, the pool sizes of propionate and succinate were of the same order of magnitude, but both were smaller by two to three orders of magnitude than the pool size of acetate.

\section{Turnover measurements}

The kinetics of acetate, propionate and succinate degradation were measured using [1$\left.{ }^{14} \mathrm{C}\right]$ acetate, $\left[1-{ }^{14} \mathrm{C}\right]$ propionate and $\left[1,4-{ }^{14} \mathrm{C}\right]$ succinate as tracers. The turnover times calculated are listed in Table 2. The turnover times of acetate in the Lake Mendota sediment and in the sewage sludge were shorter than the turnover times of propionate and succinate, which were both about the same in each environment. In contrast, the turnover of propionate in the Knaack Lake sediment was about four times as fast, and the turnover of succinate about 15 times as fast, as that of acetate.

Dividing the pool sizes by the turnover times yielded the turnover rates listed in Table 3 . The rates of total $\left({ }^{12} \mathrm{C}\right.$ plus $\left.{ }^{14} \mathrm{C}\right)$ methane formation in the experimental tubes are also shown for comparison. Acetate degradation accounted for 67,94 and $64 \%$ of total methane formation in Mendota and Knaack sediments and sewage sludge, respectively. Propionate and succinate appeared to be of only minor importance, compared to acetate, as intermediates of methanogenic degradation of organic matter, and accounted for about $4 \%$ of total methane formation in Knaack Lake, and less than $1 \%$ of total methane formation in Lake Mendota and sewage sludge. Succinate metabolism, however, was at least as important as propionate metabolism, and in Knaack Lake was about nine times faster than propionate metabolism. Thus, propionate formation and degradation could actually proceed via succinate in all three environments.

\section{Table 1. Pool sizes of acetate, propionate and succinate}

The results are shown as $\mu \mathrm{mol}$ per litre of wet sediment or sludge, \pm the range.

$\begin{array}{lccc} & \text { Mendota } & \text { Knaack } & \text { Sewage } \\ \text { Acetate } & 17.5 \pm 2.5 & 240 \pm 120 & 360 \pm 100 \\ \text { Propionate } & 0.88 \pm 0.14 & 0.32 \pm 0.06 & 2 \cdot 3 \pm 0.41 \\ \text { Succinate } & 0.68 \pm 0.11 & 0.62 \pm 0.08 & 2.0 \pm 0.17\end{array}$


Table 2. Turnover times $(h)$ of acetate, propionate and succinate

The results are shown \pm the range.

\begin{tabular}{lccc}
\multicolumn{1}{c}{ Label } & Mendota & Knaack & Sewage \\
{$\left[1-{ }^{14} \mathrm{C}\right]$ Acetate } & $0.31 \pm 0 \cdot 06$ & $40 \cdot 0 \pm 8 \cdot 0$ & $1 \cdot 2 \pm 0 \cdot 1$ \\
{$\left[1-^{14} \mathrm{C}\right]$ Propionate } & $2 \cdot 1 \pm 0 \cdot 8$ & $11 \cdot 1 \pm 4 \cdot 3$ & $1 \cdot 9 \pm 0.4$ \\
{$\left[1,4-{ }^{14}\right.$ C $]$ Succinate } & $1.4 \pm 0.5$ & $2 \cdot 6 \pm 0 \cdot 3$ & $1 \cdot 2 \pm 0.3$
\end{tabular}

Table 3. Turnover rates of acetate, propionate and succinate and total methane formation rates The results are given as $\mu \mathrm{mol} 1^{-1} h^{-1}$.

$\begin{array}{lclr} & \text { Mendota } & \text { Knaack } & \text { Sewage } \\ \text { Acetate } & 56.5 & 6.0 & 300.0 \\ \begin{array}{l}\text { Propionate } \\ \begin{array}{l}\text { Succinate } \\ \text { Total methane }\end{array}\end{array} & 0.42 & 0.029 & 1.21 \\ \text { formation } & 0.49 & 0.25 & 1.67 \\ & 83.9 \pm 24 & 6.4 \pm 2.2 & 468 \pm 48\end{array}$

* Means of total initial methane formation rates in all experimental tubes used, \pm the range

Table 4. Formation of labelled $\mathrm{CH}_{4}$ and $\mathrm{CO}_{2}$ during incubation of various labels with sediment and sludge samples

The results are percentages of the total label recovered as ${ }^{14} \mathrm{CO}_{2}$ and ${ }^{14} \mathrm{CH}_{4}$, and are means of $4-6$ independent assays.

$[1-1+C]$ Acetate

$[2-1+C]$ Acetate

$[1-1+C]$ Propionate

$[3-1+C]$ Propionate

$\left[1,4-{ }^{-1+} \mathrm{C}\right]$ Succinate

$[2,3-1+C]$ Succinate

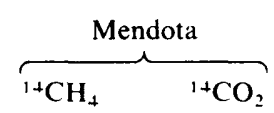

$\begin{array}{rr}3 \cdot 3 & 96 \cdot 7 \\ 87 \cdot 4 & 12 \cdot 6 \\ 2 \cdot 5 & 97 \cdot 5 \\ 48 \cdot 2 & 51 \cdot 8 \\ 1 \cdot 5 & 98 \cdot 5 \\ 48 \cdot 5 & 51 \cdot 5\end{array}$

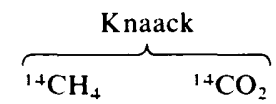

$95 \cdot 2$

$19 \cdot 5$

$99 \cdot 2$

$53 \cdot 1$

97.6

$52 \cdot 6$

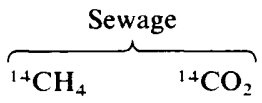

$5.8 \quad 94.2$

$97.5 \quad 2.5$

$2.4 \quad 97.6$

$\begin{array}{rl}49 \cdot 2 & 50 \cdot 8\end{array}$

$3 \cdot 0 \quad 97 \cdot 0$

$49 \cdot 8 \quad 50 \cdot 2$

\section{Mechanism of propionate degradation}

The final label distributions in the methane and carbon dioxide fractions after tracer experiments with $\left[2-{ }^{14} \mathrm{C}\right]$ acetate, $\left[3-{ }^{14} \mathrm{C}\right]$ propionate and $\left[2,3-{ }^{14} \mathrm{C}\right]$ succinate were compared with those after tracer experiments with $\left[1-{ }^{14} \mathrm{C}\right]$ acetate, $\left[1-{ }^{14} \mathrm{C}\right]$ propionate and $\left[1,4-{ }^{14} \mathrm{C}\right]$ succinate (Table 4). The labels of $\left[1{ }^{14} \mathrm{C}\right]$ propionate and $\left[1,4-{ }^{14} \mathrm{C}\right]$ succinate appeared nearly exclusively as ${ }^{14} \mathrm{CO}_{2}$, and this was also true for $>94 \%$ of the $\left[1-{ }^{14} \mathrm{C}\right]$ acetate label. The label of $\left[2-{ }^{14} \mathrm{C}\right]$ acetate appeared mainly as ${ }^{14} \mathrm{CH}_{4}$; however 13 and $20 \%$ were also found as ${ }^{14} \mathrm{CO}_{2}$ in the Mendota and the $\mathrm{Knaack}$ sediments, respectively. The label of $\left[3-{ }^{14} \mathrm{C}\right]$ propionate was converted to ${ }^{14} \mathrm{CO}_{2}$ and ${ }^{14} \mathrm{CH}_{4}$ in approximately equal amounts, and this distribution was exactly the same as that found with $\left[2,3-{ }^{14} \mathrm{C}\right]$ succinate.

The turnover kinetics of the propionate and succinate labels are compared in Fig. 1. It is evident from this figure that the labels of $\left[1-{ }^{14} \mathrm{C}\right]$ propionate and $\left[1,4-{ }^{14} \mathrm{C}\right]$ succinate are metabolized far faster than those of $\left[3-{ }^{14} \mathrm{C}\right]$ propionate and $\left[2,3-{ }^{14} \mathrm{C}\right]$ succinate. The turnover times of $\left[2,3-{ }^{14} \mathrm{C}\right]$ succinate and $\left[3-{ }^{14} \mathrm{C}\right]$ propionate were similar in each of the sediments and in the sludge. The differences in turnover times between the labels of $\left[11^{14} \mathrm{C}\right]$ propionate and $[1,4-$ 


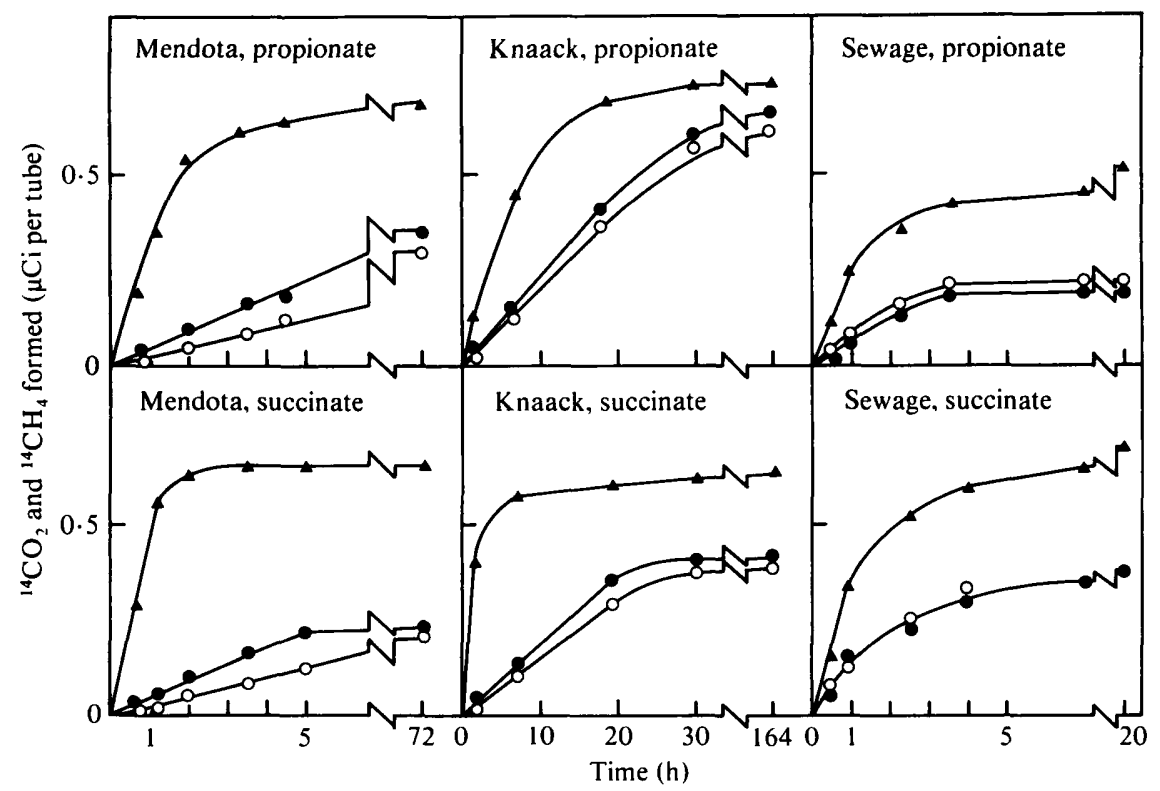

Fig. 1. Turnover kinetics of labelled propionate and succinate in sediments of Lake Mendota and $\mathrm{K}$ naack Lake and in sewage sludge. Experiments were done at the in situ temperatures as described in Methods. $\Delta,{ }^{14} \mathrm{CO}_{2}$ formation from $\left[1-{ }^{14} \mathrm{C}\right]$ propionate or $\left[1,4-{ }^{14} \mathrm{C}\right]$ succinate. Methane formation from these tracers was negligible.,${ }^{14} \mathrm{CO}_{2}$ formation and $\mathrm{O},{ }^{14} \mathrm{CH}_{4}$ formation from $\left[3-{ }^{14} \mathrm{C}\right]$ propionate or $\left[2,3^{-14} \mathrm{C}\right]$ succinate. All values are means of at least two independent experiments.

$\left.{ }^{14} \mathrm{C}\right]$ succinate, on the one hand, and those of $\left[3-{ }^{14} \mathrm{C}\right]$ propionate and $\left[2,3-{ }^{14} \mathrm{C}\right]$ succinate, on the other, were comparatively large in the Mendota and Knaack sediments (factors 3.0-18.0 depending on the substrate and the sediment used), and small in the sewage sludge (factors $1.25-$ $1 \cdot 3)$.

\section{DISCUSSION}

The aim of the present study was to compare propionate and succinate metabolism with acetate metabolism in three well-characterized anoxic environments in order to assess their relative importance and to elucidate the mechanism of propionate metabolism. The results presented were obtained during a comparatively short period in summer 1983, and therefore cannot be taken as representative of year-round metabolism in these environments. This limitation is especially important with respect to the data on Lake Mendota sediment, which undergoes a well-expressed annual change between surface oxidation in winter time and complete reduction during summer. During the investigation period, oxygen depletion in the hypolimnetic water layers was just completed, but sulphate reduction was probably quite significant as a terminal oxidation process competing with methanogenesis (Ingvorsen et al., 1981). This is indicated by the comparably high proportion of ${ }^{14} \mathrm{CO}_{2}$ formed from $\mathrm{C}-2$ labelled acetate (Table 4). Seasonal effects in the anaerobic metabolism in sediments of the meromictic Knaack Lake or in sewage sludge are probably less pronounced.

The results clearly indicate that succinate metabolism in the environments studied is at least as important as propionate metabolism; however, both are of only minor importance compared to acetate metabolism. Acetate degradation accounted for 67,94 , and $64 \%$ of total methane formation in Mendota and Knaack sediments and sewage sludge, respectively. These values are in good agreement with those published earlier, either for these lake sediments (Phelps \& Zeikus, 1984; T. J. Phelps \& J. G. Zeikus, unpublished data) or for sewage sludge (Smith \& 
Mah, 1966; Zehnder, 1978). The rates of acetate turnover and total methane formation are also in the same range as those published for the environments studied (Winfrey \& Zeikus, 1979 $a, b$ ) and for other comparable habitats (Strayer \& Tiedje, 1978; Smith \& Mah, 1966).

The turnover rates of propionate determined in this study $(0.6-4.0 \%$ of total methane formation) are low compared to those found by other authors. Balba \& Nedwell (1982) determined a propionate turnover which accounted for about $5-10 \%$ of total methane formation in a saltmarsh pond, and similar values were obtained for a hypereutrophic lake sediment (Lovley \& Klug, 1982) and for sewage sludge (Kaspar \& Wuhrmann, 1978; Mackie \& Bryant, 1981). The low rates obtained in the present study may be due to low nutrient supply, which is understandable for the lake sediments in early summer when the main substrate input from the autumn algal die-off has been largely degraded. Degradation rates for both acetate and propionate similar to those found in the present study have been reported for marine sediments (Sansone \& Martens, 1981).

The results of experiments with propionate and succinate tracers labelled in different positions allow some conclusions on the mechanism of propionate degradation. The $\mathrm{C}-1$ atom of propionate appeared exclusively as carbon dioxide, as did the C-1 and C-4 atoms of succinate. In contrast, the C-3 atom of propionate as well as the C-2 and C-3 atoms of succinate appeared as nearly equal parts of methane and carbon dioxide. In control experiments with labelled acetate, more than $94 \%$ of the $\mathrm{C}-1$ atom was converted to carbon dioxide while the $\mathrm{C}-2$ atom appeared mostly as methane. These results are in good agreement with recent studies by Koch et al. (1983) as well as with earlier findings on propionate degradation in methanogenic enrichment cultures (Buswell et al., 1951; Stadtman \& Barker, 1951), and can be interpreted as follows.

Oxidation of succinate via oxaloacetate and pyruvate yields acetate, from the C-2 and C-3 atoms, which is then cleaved to methane and carbon dioxide. Since acetate is released by the propionate-degrading bacteria, it mixes with the free acetate pool. This explains why the $\mathrm{C}-2$ and $\mathrm{C}-3$ atoms are slower to be released than the C-1 and C-4 atoms. The relatively fast acetate turnover in sewage sludge explains why the difference between the turnover times of the C-2 and C-3 labels and those of the C-1 and C-4 labels is small in this environment compared to the others studied. The degradation kinetics of the two differently labelled propionate tracers are nearly identical with those of the respective succinate tracers. Conversion of the C-3 atom of propionate to equal amounts of methane and carbon dioxide agrees with this finding and confirms the hypothesis of Koch et al. (1983) that propionate is degraded via succinate. Degradation via acrylyl-CoA or malonyl-CoA would both result in a preferential labelling of either carbon dioxide or methane (Kaziro \& Ochoa, 1964). The basic similarity of the kinetics of succinate and propionate degradation illustrated in the present paper also makes propionate degradation via methylmalonyl-CoA and succinate more likely than via 2-hydroxyglutarate, succinicsemialdehyde and succinate. Succinate turnover rates were always in the same range but slightly higher than propionate turnover rates, thus allowing degradation of propionate to proceed via succinate. This hypothesis, however, would render succinate a more important intermediate than propionate in the process of anaerobic degradation, since both production and degradation of propionate would include succinate as an intermediate.

The data presented in this paper do not allow conclusions on whether propionate conversion back to succinate includes methylmalonyl-CoA and a vitamin $B_{12}$-dependent mutase reaction. However, all bacteria forming propionate from succinate have been shown to use this pathway (Galivan \& Allen, 1968). The small free energy change of this reaction sequence $\left(-20.6 \mathrm{~kJ} \mathrm{~mol}^{-1}\right)$ can be conserved in the form of a sodium ion gradient, and thus can be used for transport purposes (Hilpert \& Dimroth, 1982) or for ATP synthesis; there is a unique anaerobic bacterium that uses this energy for growth (Schink \& Pfennig, 1982; Hilpert et al., 1984). The same amount of energy needs to be expended again in the conversion of propionate to succinate, a reaction which might again include the same four enzymes that are involved in propionate formation. From this point of view, it is enigmatic that propionate is formed from succinate by the microbial community of an anoxic sediment at all, since propionate degradation proceeds via the propionate precursor, and the energy profit of the propionateforming bacteria is the energy loss of the propionate-degrading bacteria. Nevertheless, all 
attempts in our laboratory to enrich for succinate-degrading anaerobes resulted in enrichment of propionate-forming bacteria and never in succinate-degrading syntrophic methanogenic associations. This was also true for enrichments started from most probable number dilution series spiked with hydrogen-utilizing methanogens.

The author wants to thank Dr J. G. Zeikus for providing laboratory space and equipment for the realization of this study, and is grateful to T. J. Phelps for fruitful discussions and experimental help. Thanks are also due to Professor Dr N. Pfennig and the Fakultät für Biologie, Universität Konstanz, for allowing ten weeks' research leave in Madison, Wisconsin, USA, and to the Deutsche Forschungsgemeinschaft for financial support. Financial support also came from the College of Agricultural and Life Sciences, Madison, Wisconsin, and from the Department of Energy grant DE-ACO2-80ER10705 granted to J. G. Zeikus.

\section{REFERENCES}

Balba, M. T. \& Nedwell, D. B. (1982). Microbial metabolism of acetate, propionate and butyrate in anoxic sediment from the Colne point saltmarsh, Essex, U.K. Journal of General Microbiology 128, $1415-1422$.

Boone, D. R. \& Bryant, M. P. (1980). Propionatedegrading bacterium, Syntrophobacter wolinii sp. nov. gen. nov., from methanogenic ecosystems. Applied and Environmental Microbiology 40, 626-632.

Bryant, M. P. \& SMall, N. (1956). Characteristics of two new genera of anaerobic curved rods isolated from the rumen of cattle. Journal of Bacteriology 72 , $22-26$.

Bryant, M. P., Bouma, C. \& ChU, H. (1958). Bacteroides ruminicola $\mathrm{n}$. $\mathrm{sp}$. and the new species Succinimonas amylolytica. Species of succinic acidproducing anaerobic bacteria of the bovine rumen. Journal of Bacteriology 76, 15-23.

Buswell, A. M., Fina, L. R., Mueller, H. \& Yahiro, A. (1951). Use of ${ }^{14} \mathrm{C}$ in mechanism studies of methane formation. II. Propionic acid. Journal of the American Chemical Society 73, 1809-1811.

ElsDen, S. R. \& Hilton, M. G. (1978). Volatile acid production from threonine, valine, leucine, and isoleucine by clostridia. Archives of Microbiology 117 , 165-172.

Galivan, J. H. \& Allen, S. H. G. (1968). Methylmalonyl-coenzyme A decarboxylase. Its role in succinate decarboxylation by Micrococcus lactilyticus. Journal of Biological Chemistry 243, 1253-1261.

HILPERT, W. \& DimRoth, P. (1982). Conversion of the chemical energy of methylmalonyl-CoA decarboxylation into a $\mathrm{Na}^{+}$gradient. Nature, London 296, 584 585.

Hilpert, W., Schink, B. \& Dimroth, P. (1984). Life by a new decarboxylation-dependent energy conservation mechanism with $\mathrm{Na}^{+}$as coupling ion. $E M B O$ Journal 3, 1665-1670.

Iannotti, E. T., Kafkewitz, D., Wolin, M. J. \& Bryant, M. P. (1973). Glucose fermentation products of Ruminococcus albus grown in continuous culture with Vibrio succinogenes: changes caused by interspecies transfer of $\mathbf{H}_{2}$. Journal of Bacteriology 114, 1231-1240.

INGVORSEN, K., ZeIKUS, J. G. \& BROCK, T. D. (1981). Dynamics of bacterial sulfate reduction in a eutrophic lake. Applied and Environmental Microbiology 42, 1029-1036.
Kaspar, H. F. \& WuhrmanN, K. (1978). Kinetic parameters and relative turnovers of some important catabolic reactions in digesting sludge. Applied and Environmental Microbiology 36, 1-7.

Kaziro, G. \& OchoA, S. (1964). The metabolism of propionic acid. Adtances in Enzymology 26, 283-433.

Koch, M., Dolfing, J., Wuhrmann, K. \& Zehnder, A. J. B. (1983). Pathways of propionate degradation by enriched methanogenic cultures. Applied and Environmental Microbiology 45, 1411-1414.

LAanbroek, H. J., Abee, T. \& VoOgD, J. L. (1982). Alcohol conversions by Desulfobulbus propionicus Lindhorst in the presence and absence of sulfate and hydrogen. Archives of Microbiology 133, 178-184.

LeE, S. Y., MABEe, M. S. \& JangaARD, N. O. (1978). Pectinatus, a new genus of the family Bacteroidaceae. International Journal of Systematic Bacteriology 28, 582-594.

LOVLEY, D. R. \& KLUG, M. J. (1982). Intermediary metabolism of organic matter in the sediments of a eutrophic lake. Applied and Environmental Microbiology 43, 552-560.

MackIE, R. J. \& Bryant, M. P. (1981). Metabolic activity of fatty acid-oxidizing bacteria and the contribution of acetate, propionate, butyrate, and $\mathrm{CO}_{2}$ to methanogenesis in cattle waste at 40 and $60^{\circ} \mathrm{C}$. Applied and Environmental Microbiology 41, 1363-1373.

Metcalfe, L. D., Schmitz, A. A. \& Pelka, J. R. (1966). Rapid preparation of fatty acid esters from lipids for gas chromatographic analysis. Analytical Chemistry 38, 514-515.

Nelson, D. R. \& ZeikUS, J. G. (1974). Rapid method for the radioisotopic analysis of gaseous end products of anaerobic metabolism. Applied Microbiology 28, 258-261.

Phelps, T. J. \& Zeikus, J. G. (1984). Influence of pH on terminal carbon metabolism in anoxic sediments from a mildly acidic lake. Applied and Environmental Microbiology (in the Press).

Samain, E., Albaniac, G., Dubourgier, H. C. \& TOUZEL, J. P. (1982). Characterization of a new propionic acid bacterium that ferments ethanol and displays a growth factor dependent association with a Gram-negative homoacetogen. FEMS Microbiology Letters 15, 69-74.

SANSONE, F. J. \& MARTens, C. S. (1981). Determination of volatile fatty acid turnover rates in organic- 
rich marine sediments. Marine Chemistry 10, 233-247.

Scheifinger, C. C. \& Wolin, M. J. (1973). Propionate formation from cellulose and soluble sugars by combined cultures of Bacteroides succinogenes and Selenomonas ruminantium. Applied Microbiology 26, 789-795.

Schink, B. (1984). Fermentation of 2,3-butanediol by Pelobacter carbinolicus sp. nov, and Pelobacter propionicus sp. nov., and evidence for propionate formation from $\mathrm{C}_{2}$ compounds. Archives of Microbiology 137, 33-41.

Schink, B. \& Pfennig, N. (1982). Propionigenium modestum gen. nov. sp. nov., a new strictly anaerobic, nonsporing bacterium growing on succinate. Archives of Microbiology 133, 209-216.

Schink, B., Thompson, T. E. \& Zeikus, J. G. (1982). Characterization of Propionispira arboris gen. nov. sp. nov., a nitrogen-fixing anaerobe common to wetwoods of living trees. Journal of General Microbiology 128, 2771-2779.

SMITH, P. H. \& MAH, R. A. (1966). Kinetics of acetate metabolism during sludge digestion. Applied Microbiology 14, 368-371:

Stadtman, T. C. \& Barker, H. A. (1951). Studies on methane fermentation. VIII. Tracer experiments on fatty acid oxidation by methane bacteria. Journal of Bacteriology 61, 67-80.

Strayer, R. F. \& Tiedje, J. M. (1978). Kinetic parameters of the conversion of methane precursors to methane in a hypereutrophic lake sediment. Applied and Entironmental Microhiology 36, 330-340.
Widdel, F. \& PFenNig, N. (1982). Studies on dissimilatory sulfate-reducing bacteria that decompose fatty acids. II. Incomplete oxidation of propionate by Desulfobulbus propionicus gen. nov. sp. nov. Archives of Microbiology 131, 360-365.

Widdel, F., Kohring, G. W. \& MAYER, F. (1983). Studies on dissimilatory sulfate-reducing bacteria that decompose fatty acids. III. Characterization of the filamentous gliding Desulfonema limicola gen. nov. sp. nov. and Desulfonema magnum sp. nov. Archives of Microbiology 134, 286-294.

WiNfReY, M. R. \& ZeIKUS, J. G. (1979a). Anaerobic metabolism of immediate methane precursors in Lake Mendota. Applied and Environmental Microbiology 37, 244-253.

Winfrey, M. R. \& Zeikus, J. G. (1979b). Microbial methanogenesis and acetate metabolism in a meromictic lake. Applied and Environmental Microbiology 37, 213-221.

Wolin, M. J. (1979). The rumen fermentation: a model for microbial interactions in anaerobic systems. Advances in Microbiol Ecology 3, 49-77.

Yousten, A. A. \& Delwiche, E. A. (1961). Biotin and vitamin $B_{12}$ coenzymes in succinate decarboxylation by Propionibacterium pentosaceum and Veillonella alcalescens. Bacteriological Proceedings 61, 175.

ZEHNDER, A. J. B. (1978). Ecology of methane formation. In Water Pollution Microhiology, vol. 2, pp. 349-376. Edited by R. Mitchell. New York: John Wiley. 